at Culbin planting is resorted to. From the earliest French attempts as soon as the sand was sufficiently stablished, in othel words on the landward areas where the sand was not in active movement, they sowed a mixture of the seed of the maritime pine with the two leguminous plants, the broom and Ulex, the two latter having proved indispensable in assuring the successful development of the young pine. This method has been in force for 150 years, and its success in the case of the sands in Gascony is beyond dispute ; and it is cheap. The original species planted last century at Culbin was the Scots pine. Corsican pine appears now to offer prospects of heavier crops of timber, and is to be used extensively.

Whether the experiments so far carried out justify the change from the indigenous species is at least open to doubt; and the same applies to
Pinus contorta var. Murrayana, also supposed to be a rapid timber producer. But all these species are planted. Mr. Annand writes, "The process of fixation of the moving sand is somewhat slow, and three to four years must usually elapse before tree planting can be safely commenced. The work already done, however, appears to provide sufficient evidence that the afforestation of even the most mobile of the dunes can be successfully accomplished." As a matter of fact, this latter problem has not been in doubt for the last century or more. But it would not unlikely prove of easier solution if sowing on the well-tried French lines were resorted to. As regards costs, no comparison between the French and British expenditure is possible, as no data on this head are given for Culbin. Successful sowing is, however, infinitely cheaper than planting.

\title{
Recent Excavations at the Cheddar Caves.
}

\section{By R. F. Parry.}

$\mathrm{O}^{\mathrm{n}}$ WING to the increasing number of visitors to the famous caves at Cheddar, Somerset, it became advisable in the winter of 1927-28 to enlarge the entrance. When the cave was first discovered by the late R. C. Gough some thirty years ago, access to the inner portions was obtained by making a cutting through the debris which blocked the cave immediately inside the entrance. This cutting left standing banks of untouched cave earth on either side to a height of $4 \mathrm{ft} .6 \mathrm{in}$. against the cave walls. While this original work was in progress, many pieces of ancient pottery and flint tools were found, and when in 1903 a cutting was made for drainage purposes a little farther inside the cave, other finds were made, including the skeleton known as the 'Cheddar Man,' part of a bâton de commandement, and numerous flint implements $^{1}$

These earlier finds were made without any pretence to the keeping of any record that could be of use to scientific workers, and it was with the hope of throwing some light on these that the recent necessary work of excavation was carried out in a systematic manner : the excavations were carried down to a depth of $12 \mathrm{ft} .6 \mathrm{in}$, , or $8 \mathrm{ft}$. below the level of the path; at this depth rock bottom was reached. The soil was removed in 6-in. layers (numbered from the top downwards), and passed through a fine sieve. A careful record was kept of all finds, so that it is possible to refer any specimen to both its horizontal and vertical position in the deposits.

The cave is the course of an underground stream which in olden times flowed from the present cave mouth, but when the water found the lower level that it pursues to-day the cave became a shelter and was inhabited by man.

The stratification was as follows: The upper $2 \mathrm{ft} .6 \mathrm{in}$. was composed of the well-known red cave earth. so common in the Mendip caves; this was followed by $5 \mathrm{ft} .6 \mathrm{in}$. of a mixture of cave earth

1 Seligman and Parsons, Jour. Royal Anthro. Inst., vol. 44, p. 241.

No. 3080 , VoL. 122] and sand, the proportion of sand increasing with the depth. The layers here showed in section a laminated appearance, bands of clayey cave earth alternating with bands of almost pure sand. At $8 \mathrm{ft} .6 \mathrm{in}$. a bed of gravel $3 \mathrm{ft}$. thick was reached ; it was composed of waterworn limestone pebbles with a few of sandstone, with a filling of red cave earth and sand. This was no doubt the old river bed, and the upper layers also indicate periodical flooding by the river-an event by no means unknown in recent times. Below these layers came 6 in. of sand and clay, with very few pebbles, and at depths varying from $12 \mathrm{ft}$. to $12 \mathrm{ft}$. 6 in. the rock bottom of the cave was exposed.

Now going from above downwards the upper layers showed that the cave had been occupied during the Romano-British period followed by Early Iron Age man, who left behind, amongst other things, a fine bone lance head or point very similar to one from Park Brow, Cissbury, ${ }^{2}$ and to some from the Glastonbury and Meare lake villages, pottery of distinctive types, and a bronze two-whorl ring. Immediately below these came implements of definitely Palæolithic types. Layers 9 and 10 were somewhat mixed, giving artefacts of both Early Iron Age and Palæolithic date, and showing also a mixture of recent and Pleistocene animal remains. There were no signs of occupation during the Bronze or Neolithic periods, and yet there were no blank layers, and the deposits go without a break from the Early Iron Age into the Palæolithic Age: a decidedly remarkable occurrence.

The first finds of Palæolithic date commenced in layer 7, and continued downwards to the last layer. A large number of flint implements, including knives, scrapers, borers, and burins, were found. In all, 1749 flints were taken from the excavation, 244 of which were definitely worked implements-a proportion of about 14 per cent. The long narrow flake used as a knife of the

\footnotetext{
2 R. A. Smith, Archoologia, vol. 76.
} 
gravette type with the dos rabattu back was the most common. The number of flint cores and chips point to the implements having been made on the spot. The raw flint would have to be carried a distance of some 25 miles from the nearest point at which chall flint would be available. Mr. J. A. Davies, who has reported on the flint implements, ascribes them to the Aurignacian culture developed along native lines and contemporary with the Magdalenian of France.

Perhaps the most interesting find was made in layer 19 (9 $\mathrm{ft} .6 \mathrm{in}$. deep); this was a bâton de commandement of reindeer antler. Part of another was found in the same cave in 1903 close to the 'Cheddar Man.' These are the only specimens found in England, though they are not uncommon in some of the French caves. The use of these artefacts is not very clear; some of the French archreologists consider them to be a kind of sceptre carried by the chiefs, but Sir William Boyd Dawkins and Prof. Sollas and others maintain that they were used to straighten arrow shafts. ${ }^{3}$ The latter seems to be the more likely theory. The specimen now found has a hole bored through the expanded portion of the antler where a tine branches. This tine has been cut off. The hole is bevelled on either side in a line with the shaft, and the perforation has five lines cut rather deeply on the

${ }^{3}$ W. J. SoHlas, “Ancient Hunters,” p. 530: inside, presumably to give a better grip to the arrow shaft. The instrument is ornamented on either side of the shaft by bands of lines cut lightly and rather roughly into the surface. The lines are not continued right round the shaft, each side having a separate design.

A rod of ivory and numerous bone piercers and points of a rather distinctive type were found between layers 8 - 15 , and layers 9 and 14 gave us two canine teeth of fox beautifully bored at the root ends for suspension as a necklace ornament. There was also from layer 11 a shell of Neritoides obtusatus bored for suspension.

Parts of two human skulls were found in layers 10-13. They have been submitted by Dr. N. C. Cooper to Sir Arthur Keith, who assigns them to the same age as the 'Cheddar Man,' that is, some 12,000 years ago.

The animal remains include wolf, bear and reindeer, Irish elk, arctic fox, and English varying hare.

A full account of the excavations will be published in the next volume of the Proceedings of the Somerset Archoological and Natural History Society, where the reports of Mr. J. A. Davies on the flint implements, Mr. H. St. George Gray on the bone and antler implements and pottery, Sir Arthur Keith and Dr. N. C. Cooper on the human remains, and Miss D. M. A. Bate on the animal remains, will appear.

\section{Obituary.}

Prof. Wilhelm Wien.

$\mathrm{P}$ ROF. WILHELM WIEN, of Munich, whose death on Aug. 30 last, at the comparatively early age of sixty-four years, is deeply regretted, was in the front rank of the physical investigators of his time. He was born at Gaffken, near Fischhausen, in East Prussia, where his father was a farmer, and received the earlier part of his education at gymnasia in Rastenburg and Königsberg. He then studied at the universities of Göttingen, Berlin, Heidelberg, and finally at Berlin again, where he was a pupil of Hermann von Helmholtz.

Wien's career, in its outward aspects, was very like that of most successful German men of science. He took his doctorate in 1886 with a thesis on absorption phenomena associated with diffraction. After two or three years as assistant to Helmholtz, he became a 'Dozent' in Berlin in 1892. In 1896 he became professor extraordinary at the Technical High School in Aachen. In 1899 he was appointed professor of experimental physics at Giessen; in 1900 at Würzburg, where he remained twenty years; and finally at Munich

The immense importance of Wien's contributions to physies was recognised by the award in 1911 of the Nobel Prize. His published papers cover a great variety of subjects, including hydrodynamical researches (no doubt inspired by Helmholtz), electric discharge in rarified gases, cathode rays, positive rays (Kanalstrahlen), X-rays, and, most important of all, the theory of black body radiation.
To appreciate properly Wien's work we have to remember that at the time he began as an investigator the Newtonian basis of physics was still held to be something established for all time, and Clerk Maxwell's electromagnetic theory was a new and daring speculation, regarded by many English and most continental physicists with suspicion and distrust. In fact, so far as physical principles and the underlying basis of the science are concerned, physics was thought by many to have reached a state of completion and finality. Among those who prepared the way for the splendid new era in physical science, Wilhelm Wien was one of the most prominent. His greatest achievements are embodied in the two laws of black body radiation which are named after him.

We owe the first serious attempt at a theory of black body radiation to Gustav Kirchhoff, who showed that the character of the radiation in an enclosure, every part of the walls of which has the same temperature, is independent of the nature of the materials forming the walls and is a function of the temperature only. In 1884, Boltzmann deduced from thermodynamic considerations the Stefan-Boltzmann law expressing the total energy density of the radiation in such an enclosure as a function of the temperature. The problem of the distribution of energy among different wave-lengths was still untouched, and Wien's two laws constitute an important advance in the direction of its final solution. His first paper on the subject was

No. 3080. VoL. 1221 